\title{
INSPIRASI ATT \\ (ALAT TRANSPORTASI TRADISIONAL) SEBAGAI MOTIF KAIN BATIK
}

\author{
Noor Sudiyati, Sunarto, Made Sukanadi, Pandansari Kusumo*)
}

\begin{abstract}
Historically, traditional transport is very interesting to be analyzed. The people of Yogyakarta has had various traditional transport as the artifact with different meanings. Decades ago, the traditional horse cart (andong), cart, and classic cart currently kept in the Royal Museum as well as cow cart were the reliable transport for public mobility. Other vehicles were traditional pedicab (becak) and bicycles both for male and female riders.

The artifacts have currently not been in operation any longer. Although some people have attempted to reserve the existence of those traditional transport, such as the cow cart community, traditional bicycle community, and still many others, the reservation has to be taken more seriously in order that the young generation have the sense of belonging. They have to be proud of the fact that the ancestors already had such traditional transports.

The data concerning the traditional transports was collected from the regions in Yogyakarta which still reserve the artifacts. Only few are operated, while most of them are reserved in such museums as the Royal Museum of Yogyakarta. The ancient Royal Palace used to operate their classic carts for royal events. The carts had different functions, performances, and esthetics. They also symbolize different historical meanings. The parts of the carts have high esthetic value and craftsmanship. The decoration is sophisticated and can be transformed into visualized works for further reservation.

To reserve the historical artifacts and parts with their artistic value, they are put into the motif of batik in Yogyakarta. In this way, batik Yogyakarta will be have richer motifs. Such motifs and patterns as the traditional transports as becak and bicycle are reserved on batik. It is expected that the young generation will proudly see and appreciate the wonderful historical value inherited by the ancestors.
\end{abstract}

Key Words: Traditional Transport, history, reserve, inspiration, Batik motif

\section{ABSTRAK}

Garis kesejarahan akan Angkutan Tradisional menarik untuk dikaji, Masyarakat Yogyakarta memiliki sejarah Angkutan Tradisional sebagai kekayaan artefak peninggalan, yang menyiratkan berbagai makna. ATT: Andhong, kereta, kereta klasik yang ada di Museum Kereta keraoin, serta gerobag sapi itu puluhan tahun yang lalu menjadi andalan bagi mobilitas masyarakat kita. Dilengkapi dengan becak dan sepeda onthel lanang maupun wedhok. Kini Artefak tersebut tinggal kenangan. Walaupun masih ada yang nguri-uri sebagaimana berdiri komunitas gerobag sapi, komunitas sepeda onthel dan yang lain, namun perlu dilestarikan untuk

\footnotetext{
* Noor Sudiyati (noorsudiyati@yahoo.com), Mahasiswa Program Penciptaan dan Pengkajian Seni Pascasarjana Institut Seni Indonesia Yogyakarta
} 
kepentingan generasi muda agar masih memiliki rasa handarbeni: bahwa dulu leluhurnya memiliki berjenis-jenis kendaraan tradisional.

Upaya untuk mendapatkan data dari ATTT didapatkan di daerah Yogyakarta yang masih artefak dan masih aktif dijalankan, sebagian besar sudah dilestarikan dalam museum seperti museum kereta di Keraton Yogyakarta. Kereta klasik yang pernah dimiliki kerajaan Yogyakarta tersebut bermacam fungsi, performent dan estetikanya. Semua itu bermakna, sebagai bukti sejarah Keberadaan Angkutan Transfortasi Tradisional. Artefak tranportasi itu memiliki bagianbagian yang estetis, bernilai craft yang tinggi, penuh hiasan yang rumit, semuanya menjadi obyek estetika yang dapat dilanjutkan lagi menjadi karya-karya visual yang dapat memberikan nilai kelestarian.

Untuk melestarikan artefak bersejarah dan bagian-bagian yang memiliki nilai artistic tersebut, selaras apabila dijadikan inspirasi sebagai motif batik bagi Yogyakarta, agar menambah barisan panjang motif yang dimiliki oleh dunia perbatikan kota Yogyakarta, ATT seperti becak, sepeda tersebut diangkat menjadi inspirasi untuk pola dan motif batik. Agar lestari dan generasi dapat menyaksikan dan tidak kehilangan nilai sejarah yang dimiliki para pendahulu.

Kata kunci: alat transportasi tradisional, sejarah, melestarikan, inspirasi, motif, batik.

\section{PENDAHULUAN}

Kendaran bagi setiap orang kebanyakan kini menjadi sangat penting layaknya kebutuhan pokok. Kita bisa membayangkan apabila suatu saat kita mau bepergian namun tidak ada kendaraan, yang ada semua kegiatan kita menjadi macet. Oleh karena itu kini betapa penting artinya sebuah kendaraan bagi peradaban manusia, kendaraan mendukung dinamika manusia untuk mengaktualisasikan diri, manusia menjadi sangat terbantu bahkan kendaraan termasuk hal pokok yang menjadi kebutuhan orang produktif. Kendaraan itu sendiri merupakan wahana yang akrab dan selalu mengikuti kegiatan manusia. Kita masyarakat di Jawa memiliki warisan kendaraan : kereta, Gerobag sapi, dan pedati yaitu jenis kendaraan tradisioanl yang amat unik terutama yang ada di Jawa dan DIY yang dulu sangat diadalkan, dan memiliki nilai perjuangan manusia. Namun kendaraan tersebut kini telah menjadi kenangan yang tergantikan oleh kendaran bermotor berbasis mesin. Untuk itu perlu kiranya kendaraan tradisionil yang pernah ada tersebut diabadikan agar generasi yang akan datang masih tetap ikut memilikinya, namun dengan cara bagaimana ATT tersebut diulang kembali estetikaya melalui wahana transformasi seni yang lain, misalnya dengan diabadikan dengan dijadikan ,motif batik.

Pada jaman dulu, khususnya di Jawa dan Daerah Istimewa Yogyakarta yang kini disebut DIY, masyarakatnya memiliki kendaraan tradisional yang jumlahnya pun masih terbatas, artinya tidak semua orang memilikinya, hanya para priyayi gung yang memiliki kendaraan angkutan transportasi tradisional tersebut. Pada jaman dahulu apa lagi jaman sebelum kemerdekaan, dimana jalan-jalan masih banyak berlobang, belum ada aspal di negeri ini, apalagi jalan tol seperti sekarang yang sangat mulus, sehingga laju kendaraan bisa memiliki jarak 
tempuh yang singkat. Dulu, bagi orang kebanyakan yang masih bisa disebut orang berada memiliki kereta, bagi pengusaha memiliki gerobag sapi, dan bagi para Sultan dan keluarga Raja dari keraton memiliki kereta klasik, kereta kencana, kereta kerajaan yang khusus hanya digunakan keluarga raja dan kerabatnya. Menyusul kendaraan tradisional untuk angkutan bagi peseorangan dengan jumlah penumpang minim yaitu adanya becak, dan diikuti kemudian kendaraan untuk perseorangan buatan Eropa yaitu sepeda onthel, dan inipun jarang orang memilikinya.

Kereta pedati atau andhong hingga jaman Thn 70 an masih banyak dilihat di desa-desa, kereta tersebut untuk transportasi bagi orang yang bepergian ke kota. Andhong mempergunakan satu saja binatang sebagai tenaga gerak untuk lajunya kendaraan tersebut, satu pengemudi, dan biasanya bisa dinaiki oleh 4 penumpang kecuali tambah anak balita yang bisa dipangku. Bagi para ibu yang pergi kepasar yang jaraknya agak lumayan jauh, atau belanja bagi para bakul. Andhong yang bertenaga kuda tersebut membutuhkan bahan yaitu makanan kuda yang terdiri dari rumput dan dedak, katul ( kulit padi yang halus ) yang dicampur dengan air. Type dari andhong sangat sederhana baik makanan dari pada tenaga penggeraknya (kuda), sampai kinipun andhong masih ada di daerah-daerah.

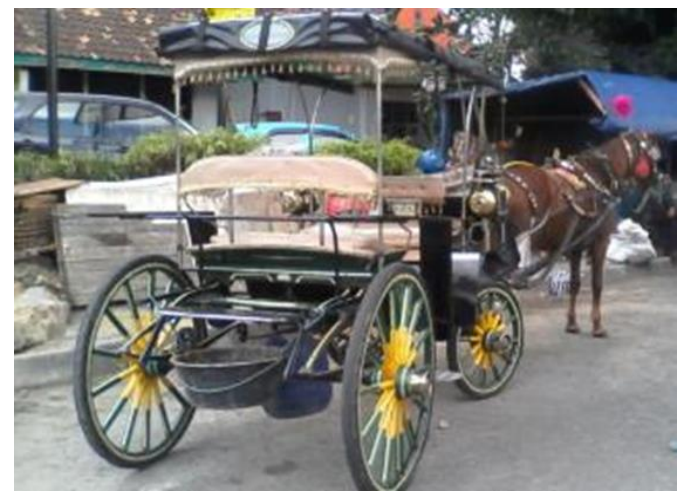

Gambar 1. Andong yang masih banyak di Yogyakarta

Kereta dokar berkuran lebih besar dari pada andhong, kereta ini umumnya ditarik oleh 2 ekor kuda, bodynya lebih bagus kualitasnya dari pada andhong, adakalanya dicat dengan warna serasi, dan memiliki roda yang sangat kokoh. Kereta ini masih dapat dijumpai di Daerah Istimewa Yogyakarta hingga kini masih sering terlihat para pelancong domestic maupun mancanegara yang berkeliling kota Yogyakarta menggunakan kereta dokar. Di alun-alun kraton Yogyakarta masih banyak dijumpai kereta dokar yang masih bagus, dan terawat, dan bermutu baik. Pada umumnya kereta yang berada di alun-alun utara Kraton Yogyakarta ini merupakan warisan dari para orang tua atau leluhurnya yang dahulu berasal dari abdi dalem kraton, mereka memiliki kereta yang sebagian unsure-unsurnya adalah buatan Eropa, dan masih asli dari jaman Pemerintahan Raja Hamengkubuwono ke VIII hingga Raja Hamengkubuwonoke IX. Kereta ini masih terawat dengan baik dan masih dipakai untuk keliling kota bagi para turis. (wawancara dengan Bapak Suharno, (42 Thn, pemilik kereta kuda dokar) . Sep. 2014. 


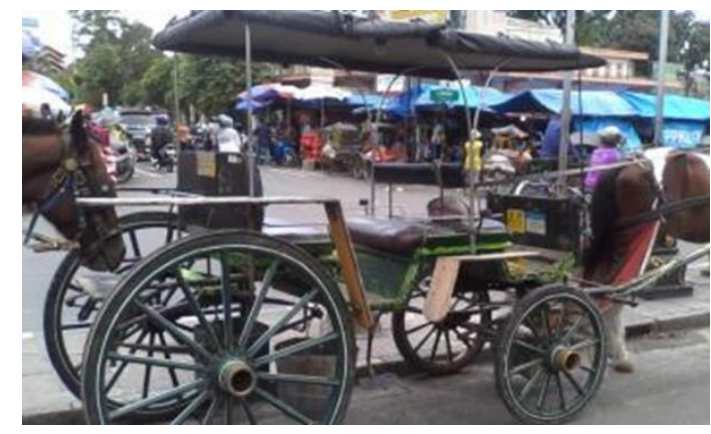

Gambar 2. Kereta yang mangkal di Malioboro

Gerobag sapi adalah kendaraan yang lebih besar dari pada andhong, lebih banyak kapasitas yang diangkutnya. Karena ruangan utamanya benbentuk kotak, sehingga lebih banyak memuat barang dengan jumlah yang banyak, baik untuk muatan barang maupun untuk mengangkut manusia sebagai penumpangnya. Gerobag sapi dahulu menjadi andalan bagi para pembawa dagangan, bagi petani untuk mengangkut hasil buminya, dan juga bagi para pejuang yang hendak menghantarkan bahan makanan untuk para perajurit di jaman revolusi. Gerobag ini bertenaga sapi untuk berjalan, biasanya dua ekor sapi tangguh yang dipilih utuk menarik barangbarang angkutannya. Dengan pola ruangan yang sederhana dan penutup bagian belakang yang mudah dibuka dengan menurunkan gribignya saja, maka barang angkutan mudah untuk dinaikkan maupun diturunkannya. Para pembawa gerobag sapi adalah ksatria yang tangguh, berani menghadapi segala rintangan, untuk mempertahankan harta benda dan keselamatannya diperlukan sikap pemberani, menghadapi malam gelap tanpa penerangan, jaman dahulu para pengemudi gerobag acapkali berhadapan dengan perampok atau begal. Sosok pembawa gerobag sapi adalah orang yang bermental baja, dahulu disebut bajingan (namun bukan bajingan yang berkonotasi jelek), akan tetapi berkonotasi tangguh dan berani melangkah menerjang rintangan.

Kereta klasik banyak berada di dalam kawasan keraton Yogyakarta, tepatnya berada di Museum Kereta Kraton Yogyakarta Hadiningrat. Semua kereta berjumlah 22 buah, masing-masing memiliki nilai dan nama serta bentuknya sendiri-sendiri, memiliki fungsi sendirisendiri dan spesifikasi hiasan yang menunjukkan eksistensi keretanya. Kereta keraton menjadi sejarah bagaimana pemerintahan dan fenomen acara-acara sakral dari Kerajaan Yogyakarta terselenggara. Merupakan warisan sekaligus pusaka yang sebaiknya dilestarikan keberadaannya, karena mengandung nilai kesejarahan bagi kerajaan Jawa yaitu Kasultanan Ngayogyakarto Hadiningrat. Visualisasi semua keretanya memiliki nilai hias, nilai teknik, dani estetika yang tinggi. Sehingga amat special satu sama lainnya. Ada kereta yang khusus difungsikan hanya untuk dinaiki keluarga raja, yaitu khusus untuk putra mahkota, ada juga kereta khusus untuk para penari, ada juga kereta untuk berburu, dan lain-lain, kesemuanya memiliki nama dan style dekorasi yang special.

Kereta klasik ini dimiliki oleh Raja Sultan Agung dan dikendarai oleh para raja keturunanya dari Hamengkubuwono I yang menurun ke raja-raja selanjutnya, hingga terakhir beberapa waktu yang lalu keretakereta difungsikan untuk perhelatan Pawiwahan Agung pernikahan Putra mahkota yaitu GKR Pembayun beserta adik-adikny. Semua kereta pada saat pawiwahan dikeluarkan dengan berbagai 
rangkaian perlengkapannya. Untuk menyiapkan karena kuda-kuda diperlukan sejumlah kuda yang banyak yang didatangkan dari kesatuan Kavaleri. Satu kereta yang sangat besar ukurannya dan memiliki bentuk yang berbeda, yaitu kereta 'Roto Praloyo', kereta ini sangat megah bentuknya, dengan hiasan bunga-bunga yang sangat simple namun sarat makna, yaitu kereta yang difungsikan khusus untuk mengangkut Raja ke peristirahatan terakhir yaitu di perbukitan Imogiri Yogyakarta Selatan. Jadi sesuai dengan namanya kereta ini satu-satunya yang untuk mengangkut Raja bila wafat. Kereta ini berwarna kuning gading yang elegant. Keistimewaan dari kereta ini adalah replica dari kereta yang ada di kerajaan inggris, yaitu di Istana Buckingham.

Semua kereta yang berada di Museum Kereta dari unsure-unsurnya memiliki dekorasi dan hiasan yang indah, sangat anggun, mewah dan elegant, masing-masing kereta hanya memiliki satu desain saja. Kereta-kereta ini diproduksi sangat special dan menjadi edisi khusus yang dibuat, hiasan-hiasanya pada bodynya dibuat dengan tangan, menerapkan ukiran manual dan dikerjakan dengan halus. Pewarnaan finishing maupun pemberian ornamentasi sagat halus dan rumit, penuh estetika tinggi. Bagian-bagian dari kereta klasik keraton sangat estetik dan menarik. Bagian -bagian dari kereta diantaranya: kursi, body kereta, jendela, dinding, kain klambu, atap, roda, lampu, bel, pecut, hiasan pintu, tempat pijakan kaki dan lain sebagainya semua digarap layak nya karya seni. Dari semua bagiannya dapat dinikmati dan dibuat dengan selera artistic serta estetika yang tinggi.

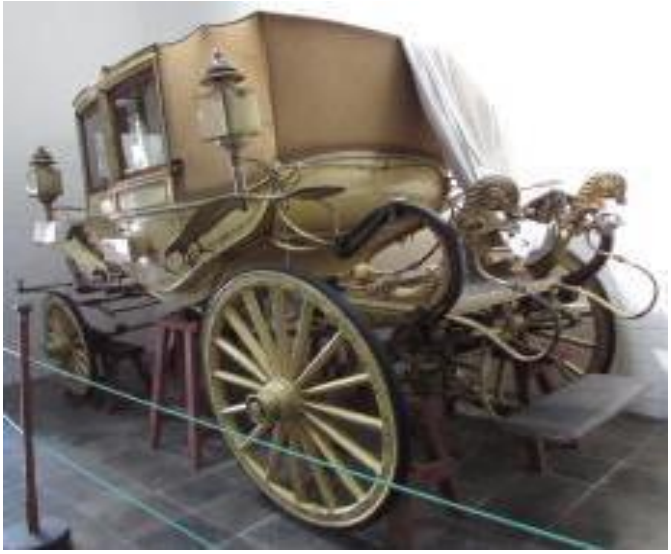

Gambar 3. Kereta Kyai Jatayu, kereta di Museum Kereta Kraton Yogyakart

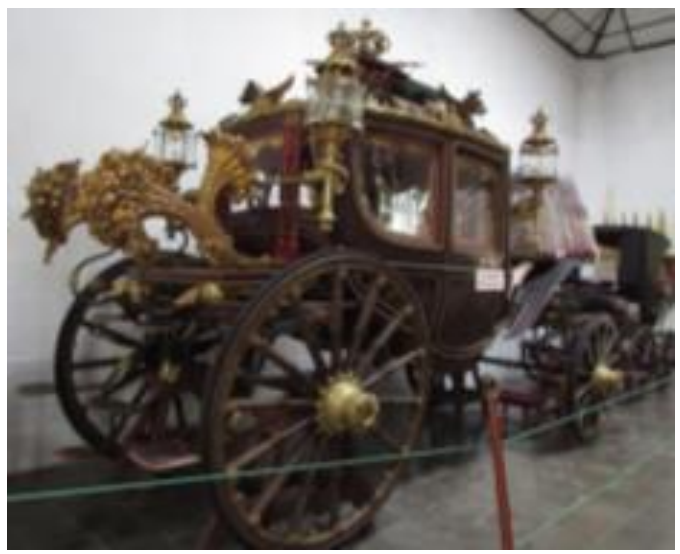

Gambar 4. Kereta kraton Kyai Garudoyekso

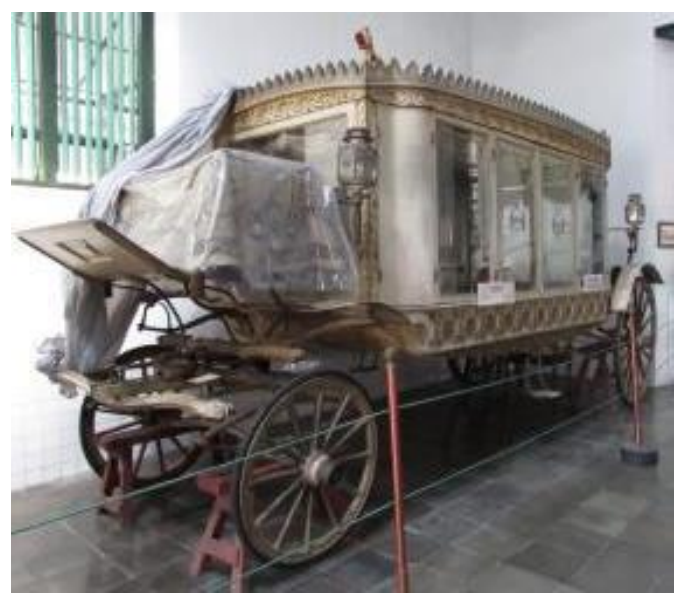

Gamba 5. Kereta Kraton Roto Praloyo Kgusus untuk mengangkut Jenazah Raja ke tempat peristirahatn terakhir 
Becak merupakan alat transportasi tradisionil, memiliki bentuk yang khas, dan unik. Becak di Daerah Istimewa Yogyakarta masih banyak di jumpai di kota, dan di daerah: Bantul, Sleman, Kulon Progo dan Gunung kidul. Becak di kota Yogyakarta amat mendukung dunia kepariwisataan daerah dan sekitarnya karena banyak turis baik domestik maupun Mancanegara yang menikmati angkutan ini, ukuranya yang kecil sehingga bisa nyelip kemana saja dijalanan kota, bisa masuk gang-gang kecil, serta disukai para pelancong untuk memburu oleh-oleh khas dari kota ini, ongkos becakpun sangat terjangkau bagi kebanyakan orang. Menikmati kota Yogyakarta dengan menaiki becak terasa berbeda, karena benar-benar merasakan nyamannya kota Yogyakarta yang tidak kemrungsung seperti di kota-kota lain. Becak yang sangat simple dan sederhana ini menambah kekayaan artefak angkutan yang ada di Yogyakarta.

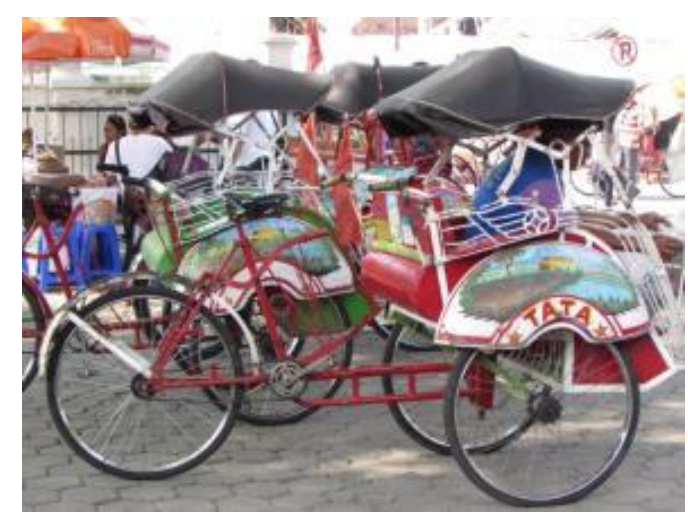

Gambar 6. Becak masih banyak di jumpai Di kota Yogyakarta

Lain halnya dengan becak, ada kendaraan tradisional yang ber roda 2 dan sangat lincah, yakni sepeda onthel, dikatakan sepeda onthel oleh karenanya roda berputar dengan cara mengayuhkan kaki. Sepeda onthel ini ada dua jenis yakni sepeda lanang dan sepeda wedhok. Sepeda wedhok bawah setang adalah melengkung sedangkan sepeda lanang bentuknya lurus plantangan.Sepeda ini termasuk alat transportasi yang sederhana dan hanya bisa dinaiki seorang saja.kecuali, jika berboncengan, sedangkan pengendaranya terbawa duduk tegak badannya sehingga sangat comfortable dan membuat sikap tubuh mejadi baik. Dengan berkembangnya waktu didorong oleh rasa dan sikap apresiasi yang tinggi terhadap artefak kuno ini, kini banyak anak muda yang memiliki komunitas sepeda onthel, bahkan orang tua juga masih banyak yang menyenagi, sehingga harga dari barang kuno ini sekarang semakin mahal karena langka dan banyak dicari orang.

Semua alat transportasi tradisional kini hanya tinggal kenangan, untuk memberikan gambaran kepada generasi muda, bahwa leluhur kita telah memiliki sejarah panjang alat transportasi yang unik, maka seyogyanya ada gerakan pelestarian terhada ATT yang memiliki kelebihan tersendiri dari alat transportasi modern. ATT memiliki nilai: kejuangan, nilai manusia dan nilai artistik dan estetika maka hendaknya dilestarikan dengan diulang kembali sebagai motif, dibuat pola-pola pada kain menjadi batik yang bisa digunakan untuk apa saja bagi masyarakat. Dengan program pemerintah melalui DIKTI dari Skem MP3EI maka tema ATT coba diangkat menjadi motif Batik.

\section{NILAI DARI ALAT TRANSPORTASI TRADISIONAL}

Manusia membutuhkan rasa
estetika, mulai dari kanak-kanak pandai


memilih mainan serta baju yang dikehendakinya, sesuai dengan keinginanya, itu artinya sudah terasah rasa estetik dan selera yang harus kita hargai. Eksistensi anak kecil dalam memilih warna baju, sepatu dan pita memperlihatkan betapa selera dan rasa estetiknya telah dimilikinya. Dan kian ingin dihargai sesuai dengan bertambahnya umur, apalagi bagi anak perempuan. Setelah dewasapun rasa estetika tersebut makin berkembang sesuai dengan jaman dan dunia lingkungannya, baik dalam lingkup bermain, lingkup sekolah, juga dalam lingkup pergaulan yang lebih luas lagi.

Begitu juga dengan orang-orang dewasa yang kian banyak kebutuhan serta kepentinganya. Untuk memenuhi kebutuhan serta barang-barang yang mendukung dinamika kehidupanya manusia menginginkan alat-alat yang tidak bisa disamakan. Dalam menunjang peradaban masyarakat memerlukan kendaraan sandang, papan dan pangan, kendaraan sangat mendukung dinamika serta mendukung kegiatan untuk bereksistensi, bahkan kegiatan dalam menyambung kehidupannya.

Berbicara kendaraan jaman dulu tentu kita tidak bisa menyamakan dengan realita yang kita lihat masa sekarang ini, dimana banyak kendaraan bermesin mulai dari motor, mobil dengan berbagai macam ukuran dan merek, mulai dari mobil mewah, mobil sport, mobil angkutan umum, mobil sedan yang di design untuk pergi ke kantor hingga mobil super mewah yang dimiliki oleh segelintir orang saja. Di Indonesia, terutama di Jawa dan Daerah Istimewa Yogyakarta baru beberapa puluh tahun saja banyak kendaraan yang semakin kompleks jenisnya. Akan tetapi pada jaman sebelum kemerdekaan di tahun-tahun 40 an kebanyakan kendaraan milik masyarakat berupa Alat Transportasi Tradisional yang berbasis tenaga manusia maupun binatang. Kendaraan dulu yang ada adalah Angkutan Transportasi Tradisional yang belum menggunakan mesin, daya lajunya masih mengandalkan tenaga dari binatang atau manusia. Body dari angkutan tradisional dibuat dengan menggunakan tangan, atau belum dicetak dengan mesin layaknya body mobil dengan perkembangan desain yang makin canggih. Angkutan tradisional yang ada di Jawa dan Daerah Istimewa Yogyakarta diantaranya adalah: pedati, andhong, kereta, kereta klasik, gerobag sapi, becak dan sepeda othel.

Kendaraan Tempo dulu Sebagaimana Angkutan Transportasi Tradisional memiliki penampilan yang unik, semua unsure-unsurnya mengandung estetika, betapa orang dahulu sudah memiliki estetika yang tinggi, bahkan kereta klasik penuh degan ukiran yang halus, ngremit dan banyak menerapkan symbolsimbol yang sarat makna. Dari sejumlah kereta yang dimiliki oleh Kraton, yang kini diletakkan di Museum Kraton masingmasing memiliki nama, dan prerforment sendiri-sendiri, memiliki estetika dan fungsinya sendiri-sendiri. Bahkan kereta "Roto Praloyo" merupakan kereta yang sangat istimewa. mengangkut Jenazah Raja ke peristirahatan yang terakhir, yakni di Perbukitan Imogiri wilayah Yogyakarta Selatan.

Dari sejumlah kereta klasik dengan beberapa nama yang masing-masing menjelaskan eksistensi keretanya, fungsi dan spesifikasinya, ada kereta yang sangat istimewa, yang diperlakukan dengan sangat 
hormat, yakni kereta "Nyai Jimat". Kereta yang bernama "Kanjeng Nyai Jimat " ini termasuk kereta yang sangat tua, namun masih menampakkan keanggunan dan keagungannya. Kereta ini acapkali diberi sesaji berupa bunga setaman atau bunga telon, perlakuan ini sudah dari jaman dahulu masih tetap lestari layaknya masyarakat Jawa yang menghormati pusaka sebagai identitas akan keyakinanya. "Kanjeng Nyai Jimat " merupakan kereta yang disakralkan. Banyak para pengunjung yang masih merasa memiliki budaya Jawa turut menghormati pusaka keraton ini.

Setiap bulan suro kereta-kereta pusaka ini dibersihkan seperti orang yang melakukan pembersihan diri untuk menyambut bulan suci atau menyambut langkah-langkah penting dalam kehidupannya. Kereta keraton banyak memberikan persepsi ulang tentang kekuasaan, pemerintahan raja, pengayoman terhadap rakyat ()kawulo alit. Dalam perjalanan dengan kereta keraton lambaian tangan seorang raja dan permaisuri di singgasana seakan menyatukan rasa handarbeni bagi orangorang lain. Tidak seperti orang yang berada dalam mobil mewah yang terjadi adalah jaraksosial antara pengemudi dan orang luar. Dari artefak kereta kendaraan Tradisional menyimpan nilai-nilai yang terbawa dari penumpang serta orang yang berada diluar sana. Dapat ditarik kesimpulan bahwasanya pada kebesaran dan estetika, serta kemewahan dan keanggunan dari kereta klasik nilainya diperuntukkan bagi 'kesesamaan'. Nilai dan makna 'kesesamaan' itulah yang mungkin tidak terdapat pada kendaraan modern.
Gerobag sapi memiliki bagianbagian yang unik diantaranya: pasangan yaitu kayu tangkai yang menghubungkan sapi dengan badan gerobag, tepong yaitu bagian belakang, kemudian gribig yaitu bagian samping bawah, Kroyong, yaitu bagian samping atas, dan payonan yaitu atap dibagian atas badan gerobag. Keunikan dari gerobag sapi adalah lembaranlembaran dari bagian badan itu terdiri dari anyaman bambu yang sangat halus, diambil dari bambu bagian kulitnya, sehingga memiliki keawetan yang cukup tinggi.

Lain lagi dengan Gerobag Sapi, angkutan transportasi Tradisional yang dikaji dari daerah Istimewa Yogyakarta merupakan angkutan yang dahulu banyak diandalkan oleh masyarakat. Gerobag sapi di masyarakat dulu banyak dimiliki oleh Pedagang atau para petani untuk mengangkut hasil panenan. Bentuk dan ukuran gerobag sapi hampir sama dan modelnyapun hampir sama. Pewarnaan dari gerobag sapi adalah khas dengan warna primer: biru, hitam dan merah yang khas. Para pemilik gerobag sapi jaman dahulu bisa dikatakan orang pemberani, karena mereka pergi menempuh perjalanan yang jauh dan jalannya masih tanah belum beraspal seperti sekarang ini, menempuh malam berhari-hari, tak ayal sering dihadang oleh penjahat atau begal di malam hari. Para pembawa gerobag sapi merupakan laki-laki yang tangguh dan pemberani, dalam artian berani melangkah utuk menjaga dan membawa harta bendanya, siapapun yang mengganggu dan menghalanginya tentu dihadapinya.

Gerobag sapi merupakan symbol rakyat, atau masyarakat sederhana yang memiliki ketangguhan dan keberanian. 
Bagaimana tidak karena para pemiliknya adalah orang-orang tangguh yang berani menerjang gelapnya malam dengan perjalanan yang tidak menentu, namun demi barang bawaan dan harta benda serta demi kehidupanya semua dihadapi dengan keberanian yang besar. Ada sebuah nilai perjuangan yang dikandungnya. Pun merupakan hubungan yang harmois antara manusia dan binatang piaraan (sapi) karena dapat bekerja sama antara manusia dan binatang. Nilai yang dapat diambil dari Angkutan transportasi jenis gerobag adalah nilai perjuangan mempertahankan hidup dan kerjasama dengan binatang serta keberanian melangkah dalam keadaan apapun, gerobag sapi mengandung nilai perjuangan tersendiri bagi orang-orang yang memilikinya.

Kendaraan tradisional yang cukup hanya dinaiki seorang saja yaitu sepeda Onthel, ada dua jenis sepeda onthel yakni sepeda onthel lanang dan sepeda onthel wedok, sepeda ini memiliki perbedaan, sepeda onthel lanang adalah sepeda yang memiliki plantangan, sedangkan sepeda onthel wedok adalah lebih luwes memiliki lengkungan dan amat estetis, karena diperuntukkan bagi perempuan, dimana perempuan itu memiliki pakaian yang sangat berbeda dengan laki-laki, yaitu memakai kain ataupun rok. Sedangkan sepeda onthel lanang diperuntukkan bagi laki-laki oleh karena nya memiliki plantangan yang sesuai dengan pakaian laki-laki bercelana panjang. Jadi sangat signifikan perbedaan kedua jenis sepeda tersebut.

Sepeda, orang memandang nya sebagai barang yang biasa dan sederhana saja, akan tetapi pada sepeda onthel memiliki fungsi yang sangat sesuai dengan kebutuhan manusia. Berkendara dengan sepeda onthel merupakan kegiatan yang menyehatkan. Dilihat dari desain dan struktur body dari sepeda membawa pengendaranya pada sikap duduk yang benar, sesuai dengan postur tubuh manusia yang baik. Sepeda buatan Eropa sangat memiliki estetika yang tinggi. Dalam mengendarainya orang kelihatan santun dengan sikap postur tubuh yang baik. Membuat sehat bagi pengendaranya.

\section{ATT di DAERAH ISTIMEWA YOGYAKARTA}

Alat Transportasi Tradisionil di Daerah Istimewa Yogyakarta ada berbagai macam jenisnya, diantaranya adalah: andhong, kereta kuda (dokar), kereta klasik, gerobag sapi, dan becak, serta sepedha onthel. Alat transportasi tersebut masih bisa dijumpai di kota Yogyakarta, Daerah Bantul, Sleman, Kulon Progo dan Gunung Kidul. Andhong yang sehari-hari masih digunakan oleh para pedagang terutama di pasar-pasar tradisional untuk mengangkut dagangan andhong datang, pagi kepasar kemudian sore pulang. Ada pula Sewaktuwaktu andhong dipakai untuk karnaval anak-anak sekolah pada hari-hari perayaan. Misalnya hari Kartini, hari Ulang Tahun Sekolah, festifal seni, dan lain-lain. Andhong ataupun kereta kuda kadang dihias dengan janur, dedaunan dan lain-lain mengesankan pelestarian tradisi danri masyarakat desa yang masih kuat.

Hal demikian menambah Yogyakarta sebagai daerah yang tradisinya masih kuat.

Kereta dokar ditarik oleh dua ekor kuda, kereta ini banyak mendukung wisata disekitar kota Yogyakarta, juga yang mangkal di alun-alun selatan, sebagai pelengkap wisata budaya, mereka menunggu para touris yang menginginkan 
jalan keliling kota dengan berkendaraan kereta dokar. Kereta dokar lebih halus penampilannya, banyak dihias dengan cat warna hijau, kuning yang menampakkan warna tradisi Yogyakarta. Kereta ini pun memiliki unsure-unsur yang menarik, diantarany: pecut, roda, lampu dan bel atau lonceng yang apabila dikaji menarik sebagai wacana tradisi yang mewakili artefak Angkutan Transportasi Tradisional.

Kereta Klasik, berada di museum Yogyakarta yang terletak didalam wilayah Kraton, sebelum masuk di Kraton sebelah utara Kraton persis ada Museum Kereta Kencana, museum tersebut menjadi tujuan wisata yang sangat menarik, adapun kereta keraton tersebut kini menjadi warisan yang sangat berarti dan merupakan pusaka keraton yang dijaga oleh bbeberapa pekathik yang sehari-harinya menjaga dan memberikan keterangan seputar keberadaan kereta tersebut kepada para pengujung. Kereta yang ada didalam Museum berjumlah 22 buah, diantaranya ada yang amat disakralkan, akan tetapi tidak mengurangi rasa keyakinan orang terhadap apa yang dipeluknya dalam masyarakat Jawa, khususnya bagi masyarakat Yogyakarta memang masih melakukan hal-hal ritual sesuai dengan budayanya. Demikian juga yang berlaku pada warisan-warisan leluhur, keberadaan kereta di Kraton yang di sakralkan selalu dijamasi pada waktu-waktu tertentu.

Kereta-kereta tersebut adalah:

1. Kereta Jong Wiyat

Kereta ini di buat pada thn 1830 buatan dari negeri Belanda, pada masa Pemerintahan Sri Sultan HB VII. Kereta ini dahulu digunakan untuk Mengangkut/ kendaraan para panglima perang (manggolo Yudo), ketika itu peperangan melawan Belanda. Namun sekarang digunakan untuk acara Pernikahan, yang digunakan untuk pernikahan putrid Sultan, yang pertama (GKR Pembayun, Putri ke dua, kemudian Putri yang ke empat Gusti Abra. Kereta ini digunakan pengantin untuk kirap mengelilingi beteng keraton., berbentuk sederhana namun memiliki keistimewaan dari model kursinya.

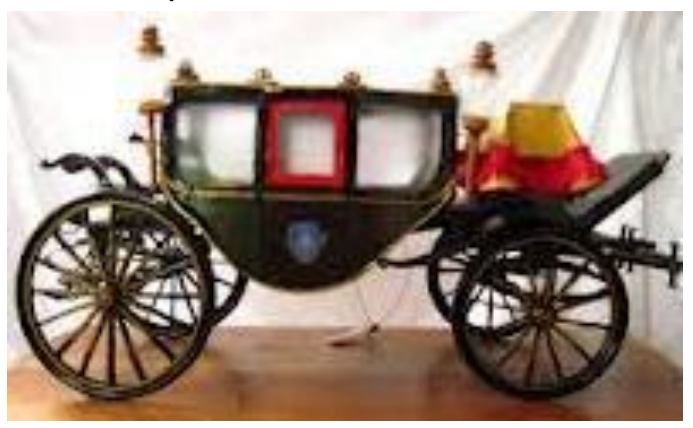

Gambar, 7. Kereta untuk Pawiwahan Agung

2. Kereta Kyai Jolodoro, kereta buatan Thn 1815, kereta ini digunakan untuk panglima perang, masih orisinil belum pernah ada perbaikan, di dalam jok nya masih mempergunakan sabut kelapa.

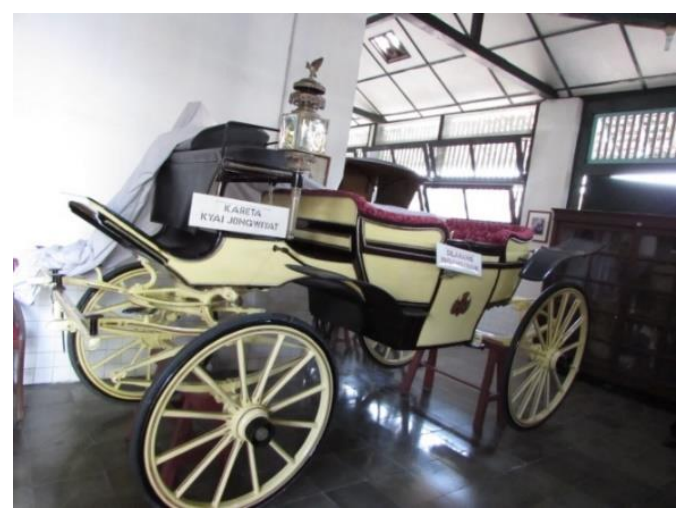

Gambar 8. Kereta Jolodoro

3. Kereta Kyai Roto Biru, Buatan Belanda thn 1901, kereta ini dipergunakan 
manggolo yudo, untuk perang ,sekarang digunakan untuk hajatan pernikahan puteri Raja HB X, yaitu kendaraan bagi besan.

4. Kyai Rejo Pawoko, kereta ini buatan Belanda Thn 1901, kendaran ini untuk keluarga raja atau keluarga Sultan, yang ditarik oleh 4 ekor kuda.

5. Kereta Kyai Landover Ngabean, kereta buatan Belanda ditarik 4 ekor kuda, digunakan oleh puteri-puteri Kraton, Buatan thn 1901 , warna..kereta ini berwarna menarik dan mewah dengan hiasan sangat klasik.

6. Kereta premili, kereta buatan thn 1921 kereta ini buatan semarang Jawa Tengah kereta ini buatan dalam negeri, berukuran besar, untuk abdi dalem yang diakui sebagai keluarga, hingga sekarang digunakan untuk kendaraan para penari, bila ada hajadan pawiwahan pernikahan puteri keraton.

7. Kereta Kus biru kereta buatan Belanda Tahun 1870, digunakan untuk para menantu raja pada saat dikenalkan kepada rakyat.

8. Kereta Kapulitin, buatan Yogyakarta, Thn 1921, dipergunakan untuk berburu.

9. Kyai Kutho Raharjo, kereta buatan Berlin (Jerman) thn1927, kereta ini digunakan untuk kendaraan para isteri raja Hamengkubuwono 7, ditarik oleh 4 ekor kuda berwarna putih.

10. Kereta Pus Gading, buatan Belanda 1901, ditarik oleh 4 ekor kuda, kereta ini khusus untuk istri raja, terakhir kendaraan ini digunakan untuk tukar cincin puteri raja yang terakhir.

11. Kereta Kyai Puspoko Manik

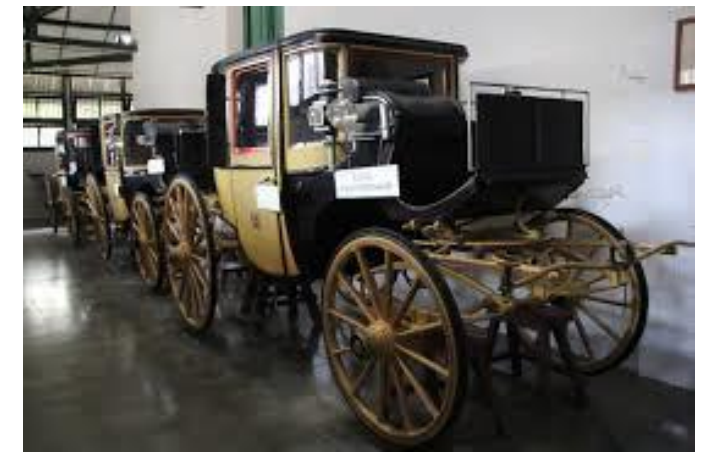

Gambar 9. Kereta yang berada di Museum dan sangat terawat

12. Kereta Manik Retno,buatan belanda thn 1815 , pada saat pemerintahan HB IV, digunakan untuk pesiar, rekreasi.

13. Kereta Kanjeng Kyai Jimat, kereta ini sangat tua umurnya, dibuat sebelum , Keraton berdiri Thn 1756, kereta ini buatan thn 1750, dari Belanda, masih orisinil, dipergunakan pada jaman pemerinthan $\mathrm{HB}$ I hingga $\mathrm{Hb}$, sekarang tidak digunakan, setiap bulan Muharam kereta ini dimandikan, dan airnya diambil oleh masyarakat untukn galap berkah.

14. Kyai Garudo Yekso, kereta buatan thn1861, merupakan Kereta Kencana, pada saat pemerintahan $\mathrm{HB} \mathrm{VI}$, hingga $\mathrm{Hb} X$ masih digunakan, kereta ini ditarik oleh 8 ekor kuda berwarna putih.

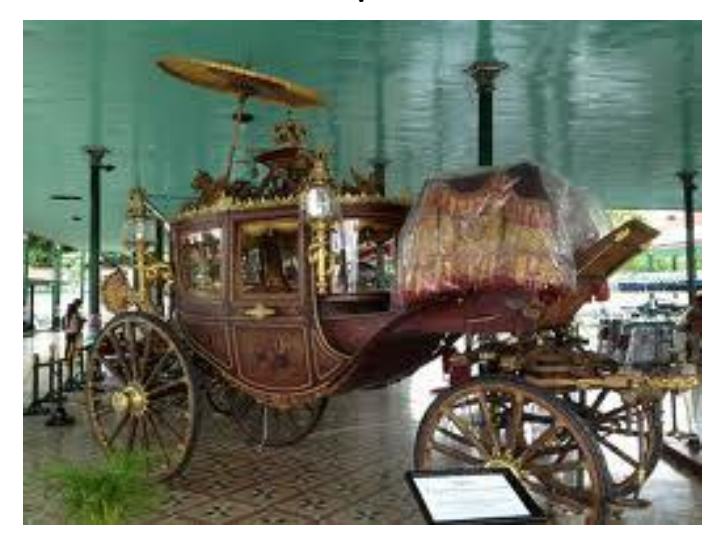


Gambar. 10. Kereta Kyai Garuda yekso Kereta khusus untuk Raja

15. Kereta Mandro Juwolo, kereta buatan Inggris Thn 1800, buatan digunakan dari HB III, ayah Pangeran Diponegoro, dahulu thn 1825 higga 1850 untuk melawan Belanda, ditarik oleh 6 ekor kuda, kaca dari body kereta anti peluru.

16. Kyai Roto Praloyo, Kereta Buatan Yogyakarta, thn1900 an Roto artinya Kereta, praloyo artina lelayu, (jenazah), dibuat pada thn 1938 masa pemerintahan HB VIII, sudah digunakan oleh Alm HB VIII dan HB IX. Merupakan Replika dari kereta Kerajaan Inggris, yang ditarik oleh 8 ekor kuda.

17. Kyai Jatayu, kereta buatan Thn 1931, buatan Yogyakarta, digunakan oleh puteri raja yang akan melihat pacuan kuda

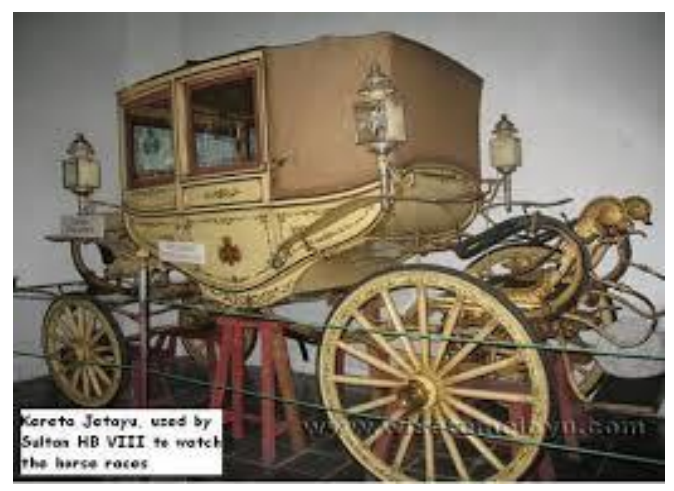

Gambar. 11. Kereta Jatayu pada masa

Pemerintahan Hamengkubuwono ke VIII

18. Kyai Harsumaba, merupakan kereta buatan Belanda Thn 1970, digunakan untuk pangeran dan putera-putera raja dari garwo ampil atau selir, kereta buatan Belanda. Di atas atap kereta terdapat (crown) mahkota yang berukuran kecil.
19. Kyai Wimono Putro kereta buatan Belanda Thn 1860, ditarik 6 ekor kuda untuk putra mahkota, memiliki symbol atas mahkota yang besar.

20. 20. Kereta Landover Wisman dibuat oleh Belanda 1901 pada masa HB VIII, ditarik 4 ekor kuda yang digunakan oleh tuan tanah (orang belanda), anthek belanda . kereta ini pada thn 1989, dikendarai oleh Pangeran Charles dari Bandara sampai Keraton, Zaman dulu digunakan juga untuk anak-anak raja yang masih kecil.

21. Landower Surabaya.

22. Landower.

23. Kyai Notopuro, buatan Belanda thn 1870, pada masa pemerintahan HB VII, ditarik oleh 6 ekor kuda putih digunakan untuk panglima perang.

\section{UNSUR-UNSUR ATT YANG MENARIK}

Berkaitan dengan dunia seni rupa dan estetika dari visualisasi Angkutan Transportasi Tradisional tersebut terdapat beberapa hal yang menarik untuk dikaji, terutama dari bagian atau unsurenya, oleh karena unsure-unsur tersebut pada proses pembuatannya mempergunakan system hanmade, kalaupun ada unsure-unsur yang dicetak dikerjakan dengan sangat perfek, seperti unsure hiasan atau ornamennya, sehingga memiliki nilai dan estetika yang tinggi. Oleh karena itu menjadi patut kita memberikan apresiaasi terhadap artefak tersebut. Dan menjadi layak jika kereta klasik diperutukkan bagi kendaraan raja atau putra mahkota maka sesuatunya harus terbaik, terbagus, dan indah, itu memberikan nilai yang tinggi, seperti pada bentuk 'crown' yang menyimbolkan kebesaran. Berbagai artefak dengan bentuk 
ini hanya dimiliki oleh keluarga kerajaan dimanapun itu, baik di Eropa, asia bahkan mungkin di kerajaan-kerajaan kecil di mana saja.

Unsur-unsur lain yang umum yang menyertai kendaraan tradisional yang sangat menarik adalah, diantaranya:

\section{Roda}

Roda merupakan unsure penting bagi sebuah kendaraan untuk transportasi baik kendaraan atau angkutan modern, maupun kendaraan angkutan tradisional, bahkan pada kendaraan modern jenis roda pun mendapatkan perhatian yang besar, baik bentuknya, ukuranya model dan typenya, ada felk dari roda khusus yang diperuntukkan bagi kendaraan sport. (sport auto) yang memiliki felk racing yang bermacam-macam dan dengan memiliki estetika tersendiri. Demikian hal nya dengan roda yang ada pada Angkutan Tradisional seperti Roda pada kereta klasik kebanyakan dibuat sangat perfek dan memenuhi estetika yang tinggi, bahkan pada as nya kadang terbungkus dengan logam berukiran yang sangat indah.

\section{Lampu}

Lampu yang ada pada kendaraan tradisional memiliki bentuk yang bermacam-macam jenisnya. Lampu juga memiliki arti yang sangat penting untuk sebuah kendaraan. Karena disamping fungsinya untuk penerangan jalan di malam hari, lampu pun menjadi elemen estetis yang pokok. Kehadiran lampu yang terbuat dari Kristal menambah kemewahan dari sebuah kereta klasik. Lampu mendukung estetika dari sebuah kerata klasik dapat diaplikasikan atau dipadukan dengan unsure-unsur yang lain. Lampu-lampu yang dijumpai pada kereta di museum kereta kraton Yogyakarta menunjukan proses pembuatan yang halus dan teliti, ada lampu yang diikuti dengan bentuk-bentuk patung klasik dari Eropa, karena kereta tersebut memang dibuat di Eropa, merupakan pemesanan lewat Kerajaan Inggris maupun Belanda pada waktu pemerintahan Kerajaan saat itu.

\section{Bel atau Lonceng}

Lonceng pada angkutan tradisional diperlukan untuk komunikasi baik kepada para sesama pengguna jalan, maupun komunikasi kepada binatang pembawa kereta.. Lonceng kebanyakan terbuat dari logam yang dicetak. Bel dapat berada menempel di body kereta namun juga bisa berada lepas (dapat dipindah). Lonceng diperlukan suaranya yang berguna sebagai tanda, atau simbol pemberitahuan, perananya amat penting untuk mengendalikan laju dan menjaga agar supaya kendaraan baik becak, andhong maupun kereta bisa berjalan dengan aman.

\section{Crown}

Crown yang ada pada kereta klasik adalah symbol atau makna kereta raja yang menandakan bahwa kereta tersebut hanya dipergunakan untuk berkendara raja atau putra mahkota. Letak dari crown bisa dimana saja, kadang di pintu, handel, dan bagian lain, akan tetapi crown kebanyakan juga berbentuk tiga dimensi berada di atas.

\section{Pijakan Kaki}

Sedemikian estetisnya sebuah kendaraan kereta klasik yang juga memperhatikan pijakan kaki yang harus sesuai dengan artinya bagai kendaraan klasik yang memang khusus untuk dipergunakan oleh 
keluarga raja. Dari sisi pijakan kaki pun dipertimbangkan efek dari fungsinya, dan harus terbuat dari logam atau bahan yang kuat. Pijakan kaki pada kereta klasik juga memiliki bentuk yang berbeda antara satu kereta dengan kereta yang lainnya.

\section{Pecut}

Pecut merupakan perlengkapan bagi pengendara untuk alat angkutan tradisional seperti kereta kuda dan kereta klasik. Pecut berbentuk panjang yang terbuat dari berbagai macam bahan yang diaplikasikan menjadi bentuk pecut. Bahan-bahan itu terdiri dari misalnya: rotan, kayu, kulit, kain, benang, manik-manik, tali, bulu-bulu, dan logam. Pecut dibuat sedemikian rupa agar supaya saat digunakan itu mengeluarkan bunyi dan menjadi sinyal atau atau kode bagi kuda. Pecut berfungsi untuk komunikasi juga antara pengendara dan kudanya.

\section{Hiasan Pintu (handle)}

Hiasan pintu atau handel pada kereta klasik terbuat dari logam yang difinisfing dengan baik, hiasan ini menjadi moment estetik tersendiri sebab hiasan tersebut mengandung nilai, karena handel pintu adalah pertama kali dilihat dan dipegang oleh penumpangnya, maka untuk kereta keraton pun memiliki hiasan pintu yang berhiaskan "crown'. Hiasan pintu memiliki ukiran yang halus, perfek, dan kalaupun itu dikerjakan dengan cara di cetak merupakan pekerjaan yang sangat halus. Hiasan pintu memiliki ornament dan makna, mengesankan kekriyaan yang dalam.

\section{Kursi}

Baik kursi untuk penumpang yang biasanya adalah keluarga raja, maupun kursi untuk sopirnya terbuat dari kulit dan adakalanya terbungkus kain beludru yang sangat kuat dan mewah.

\section{Body dari kereta}

Body kereta yang terdiri dinding-dinding kaca merupakan bangunan arsitektur yang sangat indah dan megah. Dinding-dinding kaca itu memberikan visualisasi yang mewah kepada penumpang yang ada di dalamnya. Manakala kereta kencana membawa mempelai Putri kraton yang berhias secara tradisional menggunakan adat keraton maka menampakkan kesempurnaan fungsi kereta yang sesungguhnya. Ada kesan agung dan besar kekayaan tradisi yang diwariskan dari kraton. Bukan saja untuk membawa pasangan pawiwahan agung namun satu kereta "Roto Praloyo" yang khusus dibuat untuk membawa jenazah raja yang mangkat pun menampakkan fungsi kereta yang sesungguhnya, selain memiliki fungsi juga mengandung makna-makna yang ada pada segala penampilan artefak tersebut. Begitu juga body dari gerobag sapi yang memiliki warna khas pada ornamentasinya mengisyaratkan nilai perjuangan dan kerakyatan. Becak dengan body mungilnya memberikan kesan simpel dan keramahtamahan.

\section{INSPIRASI KREATIF}

\section{Pemetaan Analisa Obyek}

Apapun benda yang terlihat ada di bumi ini memiliki bentuk dan eksistensi, dapat pula direka ulang atau bahkan langsung bisa dijadikan motif, baik abstrak maupun dekoratif dan juga realis. Dalam pengembangan motif banyak memberikan 
kemungkinan yang bisa dijangkau, yang sesuai dan selaras dengan rasa kultural kita, sehingga tetap kuat walaupun berkompetisi di kancah global. Negara-negara seluruh dunia memiliki style motif yang berbeda dan masing-masing memiliki keindahannya sendiri-sendiri sesuai dengan rasa kulturenya. (Cole: 2003).

Kendaraan Angkutan berbasis manual atau Alat Transportasi Tradisional dalam kajian ini meliputi angkutan yang beroda empat dan beroda dua, semuanya dalam kajian /ranah kendaraan ramah lingkungan, oleh sebab tidak mengeluarkan residu sisa bahan bakar dari mesin yang nyala. Andai saja semua kendaraan itu berbasis ramah lingkungan tentu tidak menyebabkan polusi di jalan raya dan menjaga keasrian lingkungan. Nilai manual yang ada pada kendaraan berbasis tradisional memberikan nilai kesahajaan, jikapun kendaraan tradisional sudah tidak beroperasi seperti dahulu, namun dari estetis dan nilai warisanya terbukti masih diapresiasi oleh masyarakat/komunitasnya. Kendaraan yang memiliki roda 4 diantaranya adalah: kereta, kereta klasik, andong, kereta dokar, dan gerobag sapi, roda tersebut berada pada as dengan garis lurus simetris yang letaknya konstan, roda memiliki ruji-ruji yang sama ukuran, serta dibuat oleh tangan-tangan ahli dan terampil. Perlakuan finishing dari ukiran, politur, pengecatannya amat halus. Jenis angkutan tradisional dibuat bagi pengendara, disamping sebagai angkutan juga dinikmati estetisnya, dalam berkendara mendapatkan kenyamanan karena menggunakan dinamika kecepatan jalannya binatang. Setelah tidak lagi berfungsi sebagai angkutan kendaraan tersebut dinikmati secara estetis, dari nilai kejuangannya serta nilai warisannya. Seperti halnya dengan Gerobag Sapi yang dinikmati nilai-nilainya, dan mampu menimbulkan lagi atmosfir daya juang dari leluhur yang mewarisinya.

Artefak Angkutan Tradisional yang kita miliki terutama di Jawa tersebut memiliki bagian-bagian yang dapat dipilah, dari strukturnya bagian-bagian tersebut memiliki keindahan dan bentuk yang artistik, semua dibuat dengan nilai craft tinggi, dengan nilai sentuhan yang halus, semacam kereta dari keraton yang memiliki ukiran dan finishing yang tinggi nilainya. Bagian-bagian dari kereta yang terangkum menjadi body, mulai: dari roda, dinding, pintu, tiang atap, dan atribut lain yang memberikan keutuhan dari sebuah kendaraan,transportasi tradisional yang penuh estetika.

\section{Perwujudan Ide Dalam Desain}

Berkarya dapat juga dilakukan dengan mengulang estetika dari karya yang lain, maupun dengan mengembangkan bentuk dari obyek rujukan yang lain. Karya seni apapun yang diciptaan oleh manusia memiliki nilai handmade, mengandung nilai harapan yang terkandung dalam makna dan dekorasi dari ornamentasinya. Sebuah artefak peninggalan bernilai guna tersirat makna dalam dekorasinya. Harapan dalam nilai guna ada pada benda-benda yang tidak biasa, artinya hadirnya artefak tersebut diciptakan dengan pemikiran-pemikiran dan nilai serta hasrat manusia yang multi dimensi. Artefak sebagai nilai guna bisa bertransformasi terus sehingga akhirnya memiliki nilai yang dimanfaatkan lagi oleh berkembangnya estetika. Alat transportasi tradisional seagai benda budaya yang memiliki nilai yang tinggi sebagai warisan. 
Dan benda warisan memiliki nilai sebagai penjaga budaya, karena itu benda tersebut menunjukkan identitas bangsa dari yang mewarisinya, karena tanpa adanya identitas bangsa itu tidak dapat dikenal lagi, sebagaimana yang berlaku pada bangsa Inca, Maya dan Aztec di Amerika Latin. (Noria Tugong: 2011. 15).

Dalam rujukan post modern seni bisa berawal dari arah manapun, baik dari ide tradisi yang dibarukan lagi, di olah lagi menjadi ide-ide lain yang bisa digarap menjadi sebuah karya. Apapun karya seni itu nampaknya kini semakin luas untuk bisa divisualkan, luas dalam arti penggunaan material maupun tema serta luas dalam genrenya. Oleh karena itu apabila sebuah kesenian tanpa adanya kreatifitas, kebaruan, aktualitas serta kejutan-kejutan yang mencerahkan bagi masyarakatnya maka seni akan menjadi sesuatu yang membosankan, ataupun menjadi sebuah tradisi yang mandeg bisa saja menjadi tradisi yang tidak memiliki arti lagi, sehingga seni tersebut akan ditinggalkan oleh masyarakatnya.( Dwi Maryanto: 2015. 15)

Gerobag sapi adalah produk budaya masa lalu, kini memiliki kegunaan dan estetika yang lain, oleh karena masyarakat memandangnya dengan cara pandang yang berlainan, artinya karena masyarakat itu dinamis maka peran dari hasil budaya berubah. Perubahan itu berlaku secara proses evolusi berasaskan pengalaman pengalaman anggota-anggota masyarakat dalam menyesuaikan dengan alam sekitar dan keperluan saat itu. (Kadir Wan Yusuf: 2006.14)

\section{Eksplorasi Bentuk}

Obyek apa saja memiliki sisi yang dapat direka ulang untuk diwujudkan kedalam visual, penelaahan bentuk menjadi pengembangan yang memiliki wujud visual dan dapat di bedah secara structural menjadi bagian-bagian untuk direka ulang kembali menjadi visual mandiri, Begitupun sesuatu bentuk akan mampu dikembangkan sesuai dengan imajinasi yang dibawa untuk perkembangan tersebut. Perkembangan dapat dilakukan melalui:

1. Rangsangan kreatifitas

2. Datangnya ide atas obyek ( materi)

3. Imajinasi yang di kaitkan pada obyek.

Rangsangan bentuk dipacu oleh adanya pendalaman terhadap outline dari obyek di hadapan atau obyek yang akan digarap, dengan begitu amat diperlukan kedekatan antara obyek dan subyek, sehingga tercipta dialog, kreatifitas berasal dari tergugahnya memori ataupun simpanan data-data yang telah kita kuasai berapapun lamanya, data tersebut dapat disebut estetika nilai yang coba kita kumpulkan dari saat ke saat, dari masalah ke permasalahan, dari solusi ke solusi yang selama ini di alami, sehingga kreatifitas tersebut menjadi anyaman memori bersifat sangat personal dan unik. Di dalam penciptaan karya hal ini umumnya kurang disadari oleh para perupa maupun pencipta seni. Anyaman memori tersebut adalah pokok yang menjadi rangsangan kreatifitas ketika saatnya tepat dan dipacu oleh hasrat yang tepat pula, kemudian nanti akan mengkaitkan lagi dengan material yang dapat diambil potensinya dari: karakternya, sifatnya, dan imajinasi yang dikandung pada materi tersebut.

Datangnya ide atas obyek yang dihadapi sebagai perangsang memerlukan 
ruang yang tepat. Dalam situasi yang tidak dapat diduga apapun yang menjadi stimulant merupakan titik tolak dari ide yang mesti dilahirkan. Kelahiran yang premature senyampang dengan jalannya waktu akan tumbuh menjadi sempurna, sehingga diperlukan kerja coknitif yang saling hadir hilir mudik memenuhi ruang seleksi. Kekayaan bathin dan pengliatan yang jernih nantinya akan membuahkan sosok yang tepat, walaupun banyak berkelindan saling hadir pilihan-pilihan yang seakan mengacaukan yang semestinya terwujud. Hanya dari latihan-latihan kepekaan nurani ide akan lahir dengan cemerlang. Di kotak mana kita berada akan mewarnai tema maupun konteks karya yang dilahirkan.

Imajinasi yang disangkutkan pada obyek seterusnya akan menjadi karya yang hidup, sementara imajinasi itu sendiri akan selalu hadir disetiap saat. Oleh karenanya bentuk-bentuk yang ada dalam imajinasi tentunya berasal dari pengalamanpengalaman batin yang tersimpan lama, bahkan teranyam dari sedikit demi sedikit. Ketika pada saatnya harus dikeluarkan untuk mengkaitkan diri dengan ide-ide maka spontan keluar sebagaimana bentukbentuk yang sudah tersedia di dalam rongga kreatifitas yang menuntut pemikiran untuk divisualkan. Urusan selanjutnya adalah pemikiran-pemikiran untuk mengeksekusi akan lahirnya karya, baik menyangkut bahan, teknik, perhitungan: ukuran, estetika, tema, dan banyak hal lagi yang ikut teranyam dalam kepentingan karya tersebut.

\section{Pengembangan / Hasil}

Pengembangan hasil seni rupa yang berasal dari penggarapan terhadap seni sebelumnya akan memiliki nilai runutan yang kadang sama sekali bentuknya sudah lari. Pada bagian-bagian unsure yang ada di angkutan tradisional yang digarap lagi, dikembangkan menjadi wahana seni baru dihubungkan dengan teknik batik, maka terlahirlah motif-motif yang terdiri dari gambaran-gambaran ataupun bentuk unsure Alat Angkutan Tradisional. Ternyata dari unsure-unsur ATT itu banyak sekali yang bisa digarap dan sangat luas apabila dikembangkan ke seberapa deformasi yang mampu mengikuti. Dari bentuk-bentuk yang unik sederhana melalui style dari sifat dekoratifnya batik akan tercipta banyak bentuk maupun motif yang dihasilkannya. Dalam style motif-motif batik memiliki pengembangan yang khas, yang banyak memunculkan unsure dekorasi dan benarbenar dapat merunut pada seni hias yang mengandung nilai jawa, dan mencerminkan luwesnya pribadi-pribadi yang jumeneng, para pembuat batik dan komunitas pencinta batik yang sudah mendalami apa arti kata batik mencerminkan keselarasan dalam hidupnya.

\section{METODE}

Penelitian yang dialakukan untuk mengkaji Alat Transportasi Tradisional ini dilakukan langsung ke lapangan di Wilayah Daerah Istimewa Yogyakarta: Bantul, Sleman , Kota, Kulon Progo dan Gunung Kidul, dari datadata yang terkumpul memberikan kenyataan bahwa ATT masih di apresiasi oleh masyarakat. Untuk melestarikan ATT agar generasi penerus mempunyai rasa kepemilikan dari sejarah ATT milik leluhurnya maka dipetakan bagian-bagian atau unsur dalam ATT yang memiliki bentuk unik, direka ulang menjadi wahana seni yang diperbarui, yakni dijadikan motif batik 
dan pola-pola untuk Batik Yogyakarta supaya menambah jenis motif bagi dunia perbatikan di Yogyakarta. Obyek-obyek ATT dicermati dan olah menjadi imajinasi, distilisasi dan di garap menjadi wujud motifmotif batik yang masih memiliki nilai-nilai ATT, baik bentuk, komposisi, bagian-bagian serta isian-isiannya.

\section{DESAIN YANG DIHASILKAN DARI ARTEFAK}

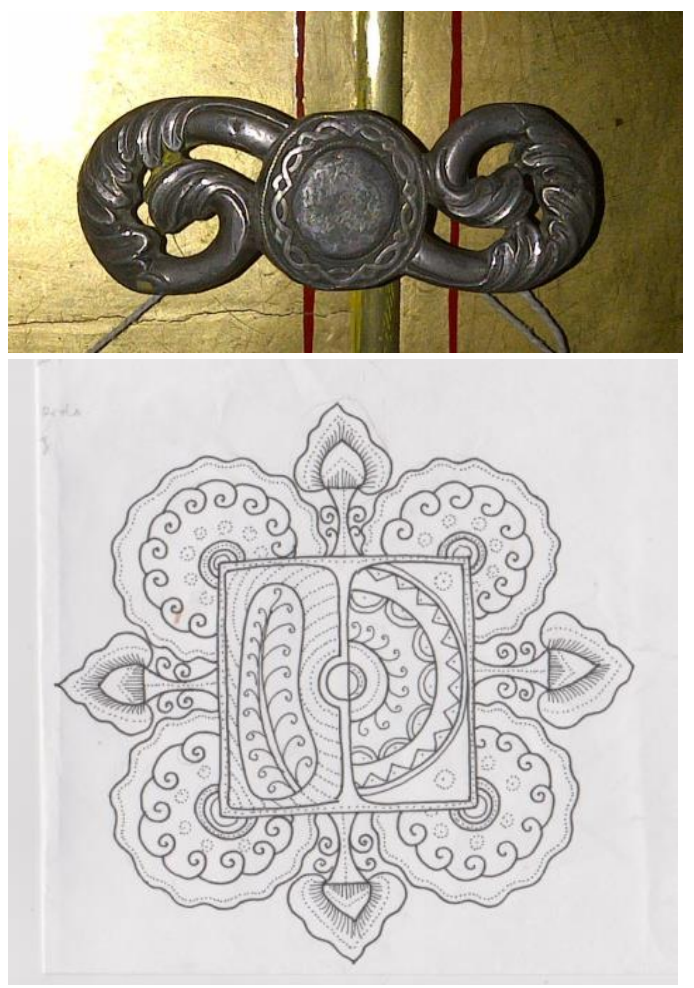

Gambar.12 Pengembangan dari handel pintu
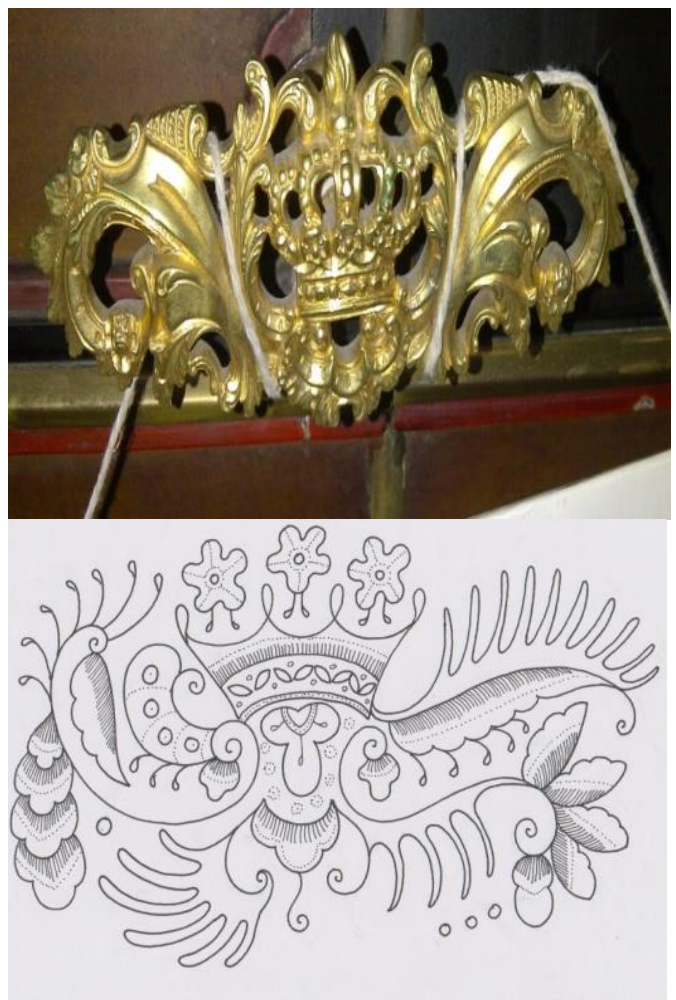

Gambar. 13 Pengembangan Handel pintu menjadi Motif pola Batik
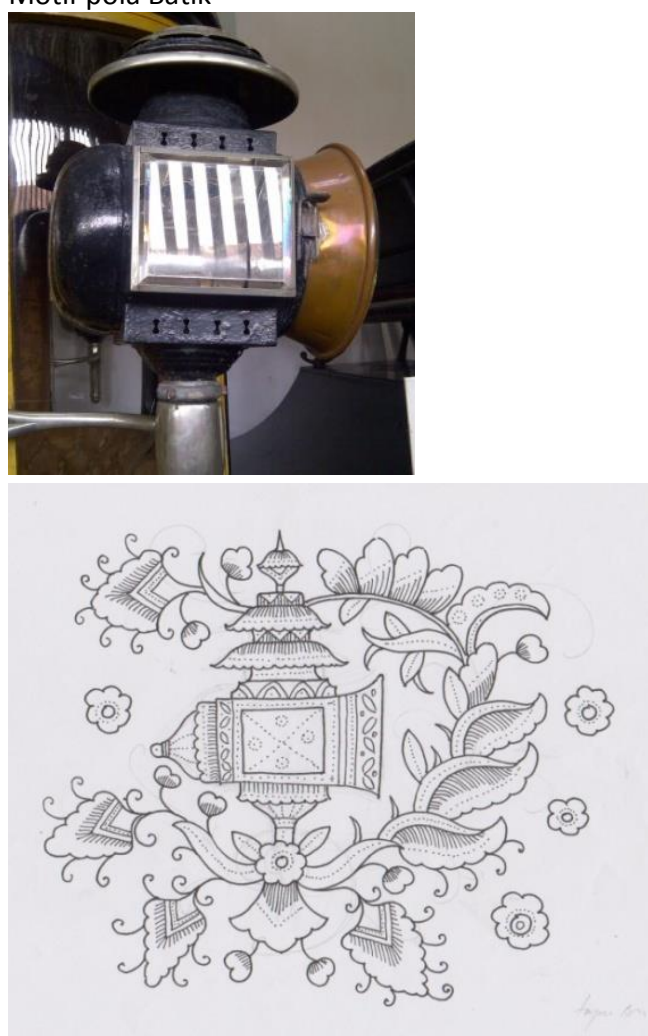

Gambar.14 Lampu menjadi motif Pola Batik 

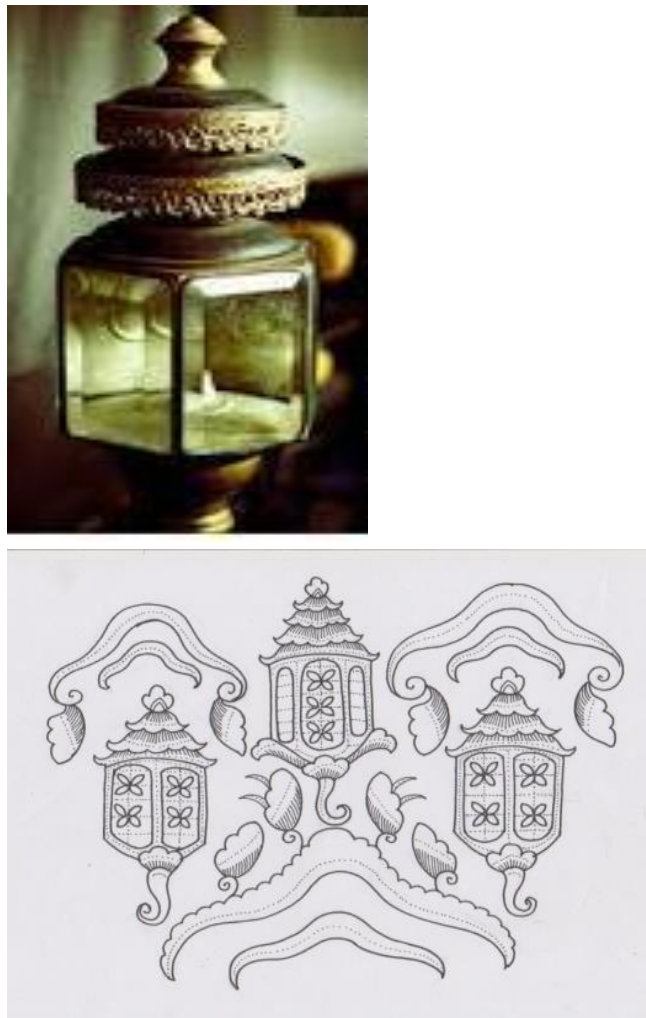

Gambar.15 Lampu menjadi motif pola Batik
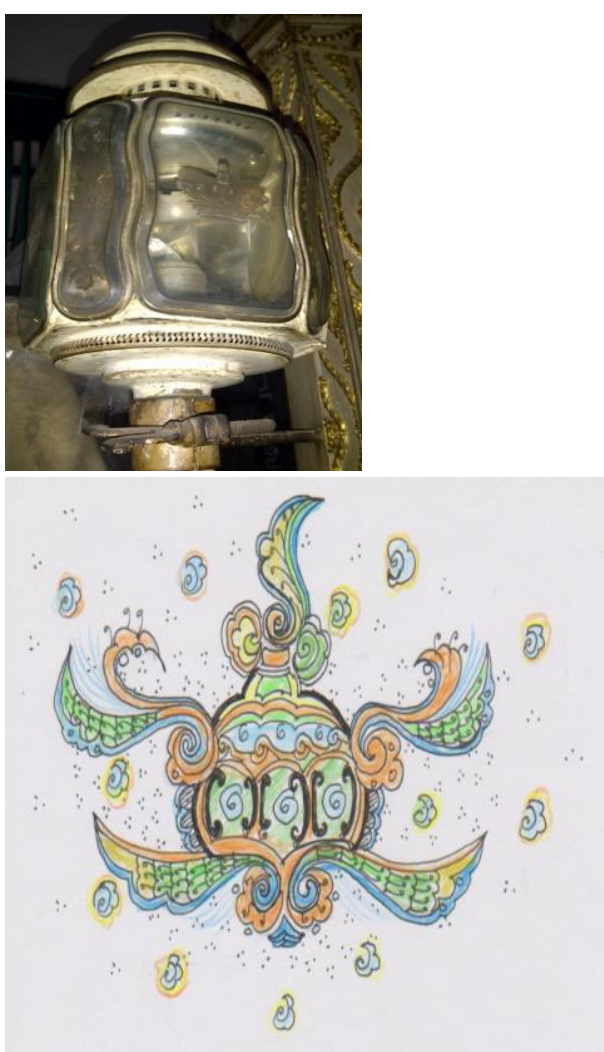

Gambar.16 Lampu menjadi ceplok pola Batik
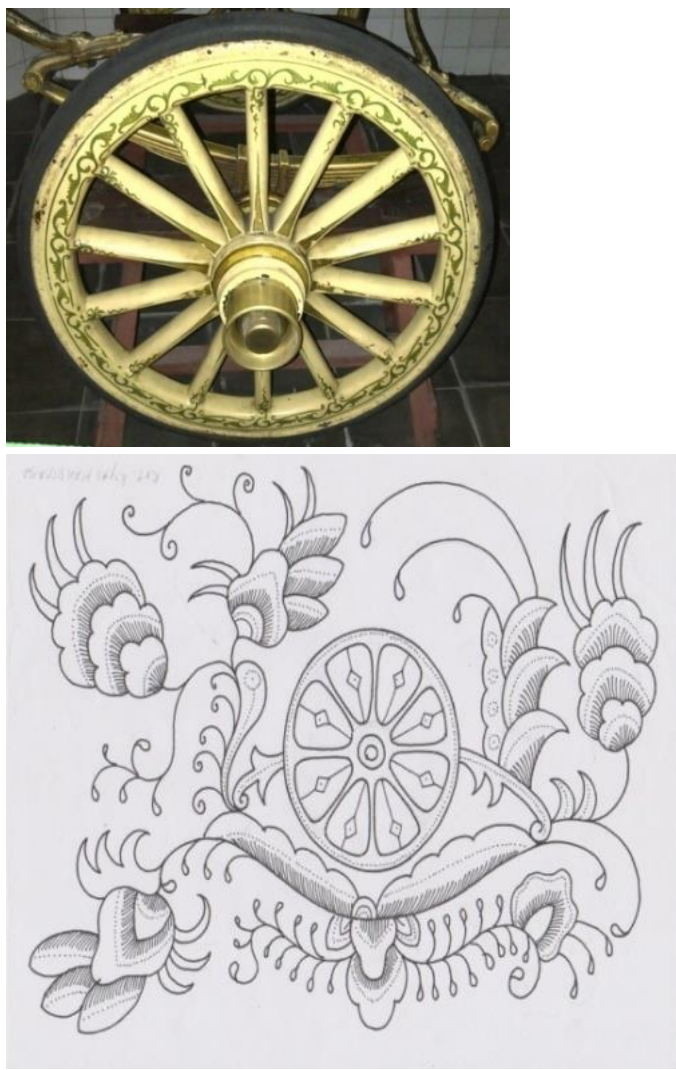

Gambar.17 Roda menjadi Pola Batik
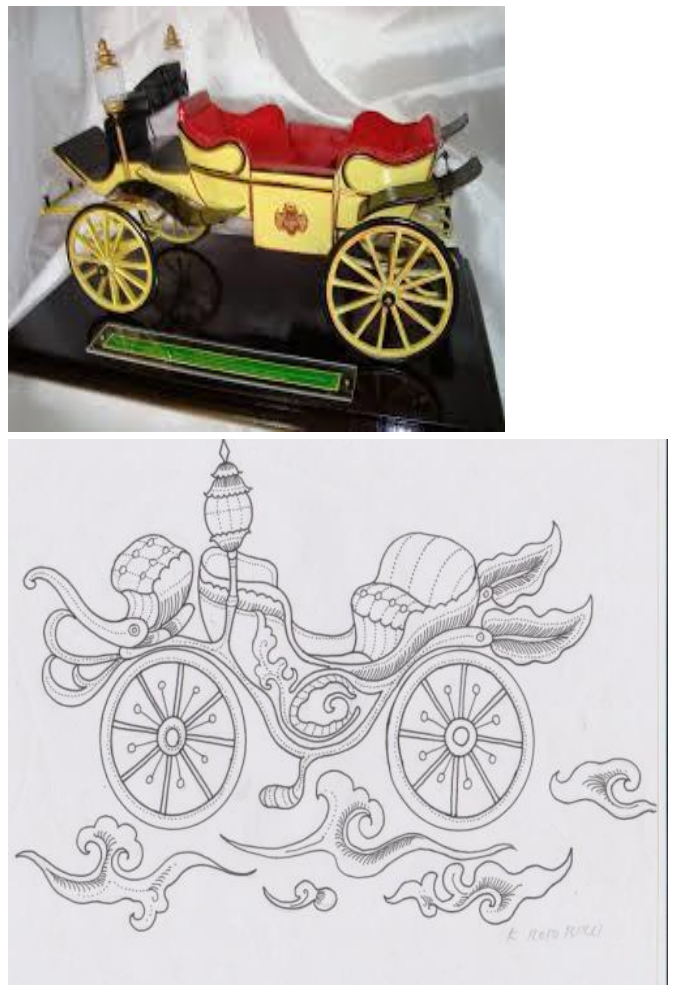

Gambar.18 Kereta Keraton Menjadi Pola Batik 


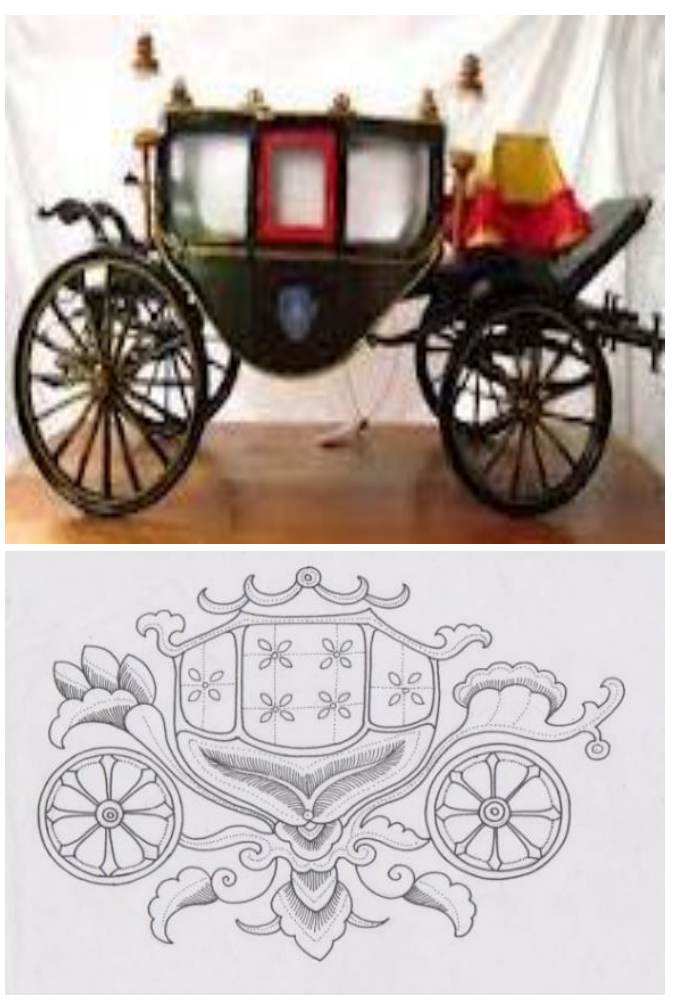

Gambar . 19 Kereta menjadi pola Batik
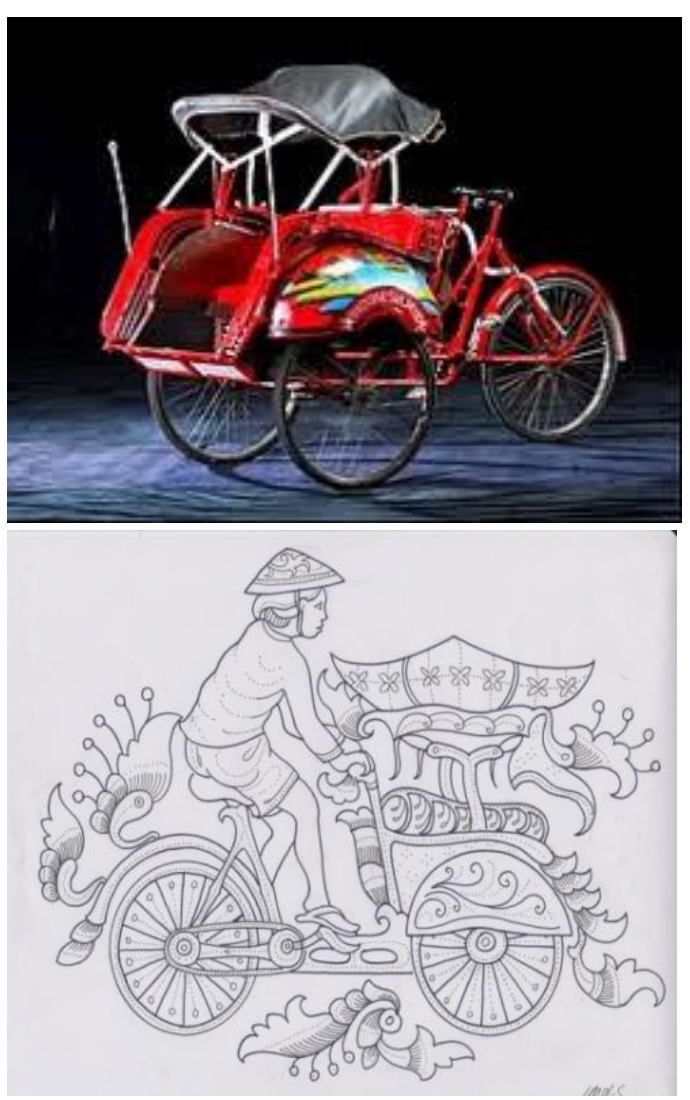

Gambar.20 Becak menjadi Pola Batik
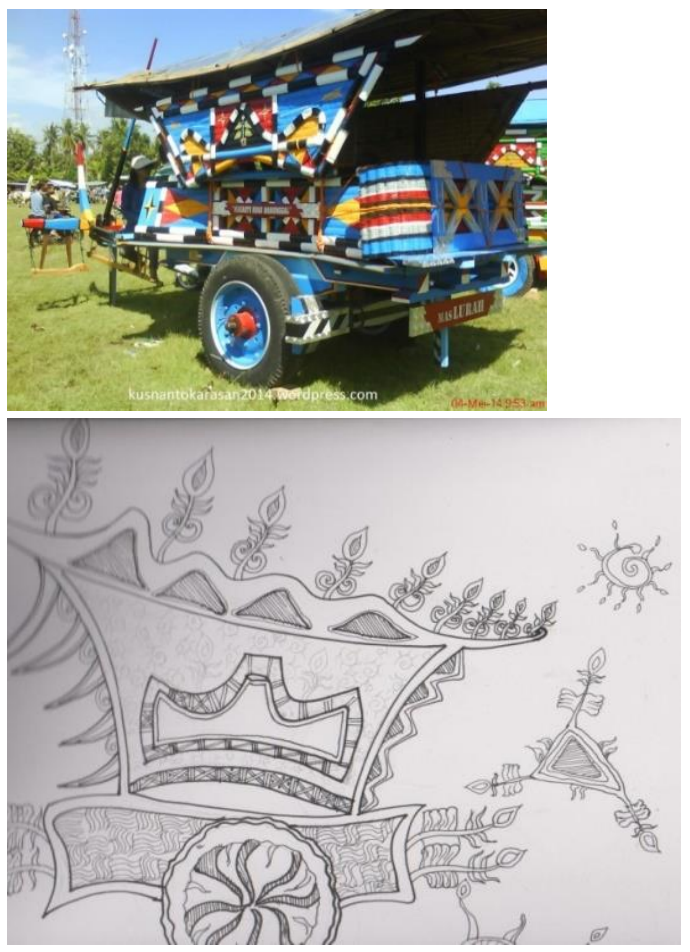

Gambar 21. Gerobag Sapi menjadi Pola Batik
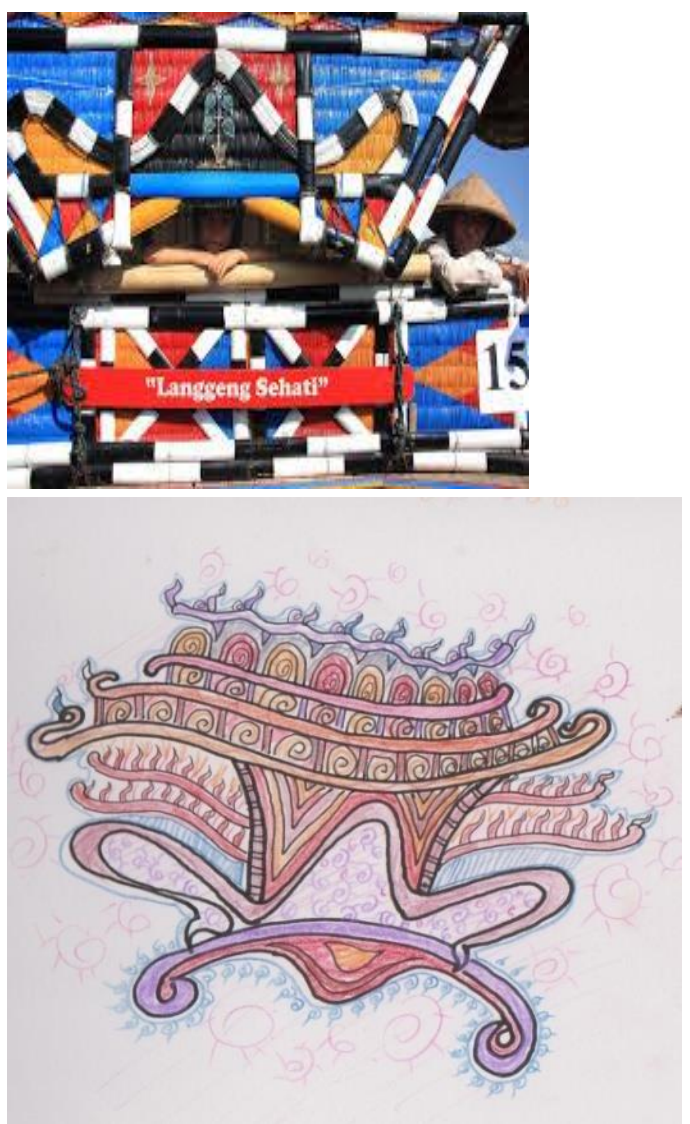

Gambar.22 Gerobag Sapi menjadi Pola Batik 


\section{PENUTUP}

Penelitan dilakukan: dari mengkaji obyek-obyek ATT hingga mencoba untuk memperbarui kembali pada seni batik dengan menciptakan motif-motif. Dari hasil yang sudah dianalisa memiliki kesimpulan bahwa: obyek ATT yang unik dan memiliki nilai-nilai yang tinggi berpotensi untuk digali kemungkinan-kemungkinan

pengembangannya. Permasalahannya dapat dikembangkan menjadi pewarisan, dan juga dapat menjadi seni yang diperbarukan lagi, dikembangkan sebagai motif batik Yogyakarta yang unik, dan kreatif. Dan ini belum pernah digarap secara maksimal. Maka apabila dilakukan penggalian lebih dalam dan diangkat untuk dijadikan inspirasi akan memiliki daya tawar yang sangat tinggi dan luas. Saran untuk pengembangan lebih jauh lagi yaitu supaya kalangan pelaku seni dapat lebih giat lagi untuk menggali artefak khususnya ATT supaya nilai dan kelestarianya tetap dimiliki oleh bangsa kita.

\section{DAFTAR PUSTAKA}

Alwi, Hasan. 2000. Kamus Besar Bahasa Indonesia. Edisi ke tiga Departemen Pendidikan Nasional: Balai Pustaka, Jakarta.

Asmujo Jono Irianto. 2009. Warisan Tradisi dan Seni Rupa Kontemporer, Makalah Seminar Nasional, Pengembangan Kesenian Tradisional dalam Kebudayaan Kontemporer.Jurusan Seni Rupa Fakultas Bahasa dan Seni Universitas Negeri Semarang.

Adi Kusrianto. 2013. Batik Filosofi, Motif \& Kegunaan. Andi. Yogyakarta.
Ari Wulandari. 2011. Batik Nusantara: Makna, Filosofis, Cara Pembuatan\& Industri Batik. Yogyakarta: Andi.

Asti Musman \& Ambar B. Arini.2011. Batik, Warisan Adiluhung Nusantara, Yogyakarta: Andi.

Bandem, I Made. 2005. Kekhasan Penelitian Bidang Seni, Forum Diskusi Penelitian dan Pengabdian Kepada Masyarakat Bidang Seni DP3M Dirjen Dikti Depdiknas RI 7- 9. Denpasar. Desember 2005.

Condronegoro Mari2010. Memahami Busana Adat Kraton Yogyakarta. Warisan Penuh Makna.Yogyakarta: Yayasan Pustaka Nusatama.

Djumena Nian S. 1990. Ungkapan Sehelai Batik"Its Mystery and Meaning", Jakarta: Djambatan.

1990. Batik dan Mitra, Batik and is Kind, Jakarta: Djambatan.

. 1991. Batik dan Mitra, Jakarta, Jambatan.

Drusilla Cole. 2003. Design Throught The Centuries, 1000 Patterns. USA. Chronicle Fransisco.

Gustami ,SP. 1992. "Filosofi Seni Kriya Tradisional Indonesia", dalam SENI: Jurnal Pengetahuan dan Penciptaan Seni, II/01, BP ISI Yogyakarta, Yogyakarta.

\begin{tabular}{lrrr} 
& 2004. & Proses & Penciptaan \\
\hline Karya & Seni & Kriya & Untaian \\
Metodology, Yogyakarta & Program \\
Pascasarjana ISI Yogyakarta.
\end{tabular}
2008. Nukilan Seni Ornamen Indonesia, Yogyakarta:Jurusan Kriya 
Fakulta Seni Rupa, Institut Seni Indonesia Yogyakarta.

John Naisbitt. 2006. Minsed, Tata Pola Pikir untuk Membaca Peluang Bisnis Masa Depan \& Menuai Profit, Jakarta:Daras.

Kadir Wan Yusuf. Wan Abdul. 2006. Wacana Budaya. Kuala Lumpur Pustaka Wira Sdn Bhd.

Michael Hitchock. 1991. Indonesian Textiles, Berkeley Singapore: Periplus 'Editions.

Notonegoro. 2008. Kraton Yogya, Warisan dan Budaya, PT Jayakarta Agung Offset .Jakarta :Indonesia Kebanggaanku bekerjasama Indonesia Marketing Assosiation.

Sidik, Fajar dan Aming Prayitno, tt., Desain Elementer, Fakultas Seni Rupa, Institut Seni Indonesia Yogyakarta....

Sularto, tt., Monografi Daerah Istimewa Yogyakarta, Proyek Pengembangan Media kebudayaan, Direktorat Jenderal Kebudayaan Departemen Pendidikan dan Kebudayaan Republik Indonesia ..

Susanto, S.K. Sewan. 1984. Seni dan Teknologi Kerajinan Batik. Jakarta: Departemen Pendidikan dan Kebudayaan Direktorat Jenderal Pendidikan Dasar dan Menengah, Direktorat Pendidikan Menengah Kejuruan, Proyek Pengadaan Buku Pendidikan Menengah Kejuruan.

Suyanto, A.N. 2002."Sejarah Batik Yogyakarta", Rumah Penerbitan Merapi kerjasama dengan Yayasan Adi Karya IKAPI Ford Foundation.

Suryo Tri Widodo. 2009. Eksistensi Seni Batik di Indonesia Dari Aspek Sosial dan Politik dari Era Kerajaan ke Era Republik, Prosiding Seminar Nasional Seni Kriya, Kriya: Kesinambungan dan Perubahan, Jurusan Kriya Fakultas Seni Rupa dan Desain ISI Yogyakarta dalam Rangka Purna Tugas Prof Gustami. Yogyakarta 5 Mei, 2009.

Sudewi Samsi. 2011. Sri, Teknik dan Ragam Hias Batik. Yogya: Titian Masa Depan.

Suyani. 2014 Sentra Industri Batik Lendah Kulon Progo, Tesis Program Pascasarjana Institut Seni Indonesia Yogyakarta, Juni.

Tugang, Nuria. 2011. Tembikar Dalam Budaya Iban Di Serawak. Malaysia: Universiti Malaysia Sarawak Malaysia.

Van Der Hoop, A.N.J. Th. A. th,, 1949, Indonesishe Siermotieven (Ragamragam

Perhiasan Indonesia), Kunsten En Wetenschappen: Koninklijk Bataviaas chap Van.

Wuri Handayani, 2011, Batik Cirebon, Bentuk, Makna dan Fungsi, , Tesis Program Pascasarjana, Institut Seni Indonesia. 